\title{
INSTRUMENTOS LINGUÍSTICOS E DISCURSOS DE DISPONIBILIZAÇÃO DE/EM INSTRUMENTOS DIGITAIS DE APRENDIZAGEM ${ }^{1}$
}

\section{Cidarley Grecco Fernandes Coelho*} UNICAMP

Resumo: Pela História das Ideias Linguísticas, este trabalho faz uma análise da relação entre tecnologia e ensino, a partir de um fragmentário de saberes, com sua historicidade sobre a língua, disponíveis em rede digital. Levando em conta que Estado, instituições e saberes se apresentam na divisão dos sentidos, na tensão entre o dito e o não dito, considerando a contradição e o político - a análise busca a opacidade nos discursos de disponibilização de conteúdos educacionais em redes digitais. A análise possibilita refletir sobre o caráter material e o processo de significação dos instrumentos linguísticos pela sua historicidade, como objetos históricos e discursivos - e na sociedade contemporânea significada pelo digital. Compreender os processos de significação desses instrumentos, em sua dispersão, é o objetivo. Além disso, também se e como a materialidade digital passa a (re)significar esses objetos enquanto instrumentos que constituem os saberes linguísticos relacionados ao ensino da língua.

Abstract: Based upon the History of Linguistic Ideas, this work analyzes the relationship between technology and teaching, based on a fragmentary knowledge, with historicity about the language, available in a digital network. Taking into account that the State, institutions and knowledge present themselves in the division of the senses, in the tension between what is said and what is not said, considering the contradiction and the political - the analysis seeks the opacity in the discourses of educational contents available in digital networks. The analysis makes it possible to reflect on the material character and the process of meaning of the linguistic instruments by their historicity, as historical and discursive objects - and in the contemporary society signified by the digital. Understanding the processes of meaning of these instruments, in (cc) $\mathrm{EY}-\mathrm{NC}-\mathrm{SA}$

Líng. e Instrum. Linguíst., Campinas, SP, n. 44, p.78-111, jul./dez. 2019 


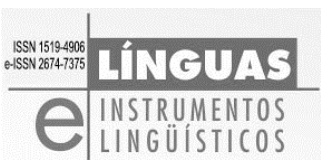

their dispersion, is the goal. In addition, if and how digital materiality (re)signifies these objects as instruments that constitute the linguistic knowledge related to language teaching.

\section{Introdução}

Quando uma linda peça de cristal se quebra... Um cristal não se quebra. ${ }^{2}$ Comecemos por isto. O cristal se fragmenta. Há uma diferença importante aí. O vidro é classificado como uma substância amorfa, já o cristal é uma substância (mineral ou orgânica) dotada de um arranjo ordenado de seus átomos, íons ou moléculas. As partículas que se estilhaçam quando o cristal toca o chão são resultantes de sua clivagem, ou seja, de sua tendência a seguir determinadas direções ao se romper. Alguns cristais apresentam clivagem dita perfeita, como a calcita. Outros, uma clivagem sem nenhuma direção como é o caso do quartzo. Chamamos a atenção para a definição da clivagem de alguns cristais: "dita perfeita", o que é bem diferente de dizer que é perfeita, embora a imagem da estrutura atômica do cristal possa ser tomada como perfeita se comparada ao vidro. Mas não nos enganemos. Não há ritual sem falhas, diz Pêcheux (1995).

Os cristais podem ser formados a partir de uma solução, de uma fusão, de vapores ou de recristalização. Os arranjos cristalinos, agrupados em paralelo na superfície interna, podem formar drusas ou geodos, com muitos ou poucos cristais dependendo da pressão. É possível fazer um cristal em casa: o cristal sintético. Há também o cristal líquido, como o que pode servir para a leitura deste texto em um aparelho digital. Seu estado é um estado especial. Um entremeio ${ }^{3}$ talvez. Entre o líquido e o sólido. Estado mesomórfico, com propriedades dos líquidos, como fluidez e mobilidade molecular, mas também dos sólidos, como birrefringência e anisotropia óptica e elétrica. Foi descoberto em tecidos vegetais. Geralmente, são orgânicos. ${ }^{4}$ Seu uso hoje é digital. No entremeio das relações entre sujeito e máquina.

Somos sujeitos digitais. Olhamos para o cristal líquido frequentemente sem nos darmos conta de sua especificidade. Muito menos suas moléculas se dão conta da nossa. Quando o cristal líquido de nossas telas se rompe, perdemos nossos dispositivos. Quando uma peça de cristal toca o chão, estilhaços se espalham e dificilmente conseguimos juntar os resultados dessa clivagem perfeita. E quando os saberes de instrumentos

Líng. e Instrum. Linguíst., Campinas, SP, n. 44, p.78-111, jul./dez. 2019 
linguísticos ${ }^{5}$ se dispersam no digital, perdemos nossos referentes? Somos sujeitos organizados e constituídos por uma ordem. ${ }^{6}$ Também históricos, políticos, ideológicos, simbólicos, vivendo em espaços histórico-sociais. Portanto, olhar para o aspecto histórico, ideológico e discursivo da tecnologia digital, e para as consequências no que tange ao sujeito, à ciência e à sociedade se faz fundamental. Por isso, buscamos compreender o funcionamento de tecnologias de linguagem desenvolvidas no domínio das tecnologias de leitura e escrita, e estas como uma forma de relação social, como propõem os trabalhos desenvolvidos por Orlandi (2008) e sua equipe que se espalhou pelo Brasil e ganhou corpo. É importante destacar também que aqui vamos considerar o digital, na perspectiva teórica de Dias (2014), como espaço de transformação das relações.

Consideramos, principalmente no que diz respeito à escola, a transformação da relação do homem com a linguagem, no caso, com a leitura e a escrita, que desencadeia outros processos de transformação: a forma dos textos, o modo de significar, o posicionamento dos sujeitos nos discursos pedagógicos, as maneiras de ser e estar em rede. Seguindo esse pressuposto, a proposta é fazer uma cartografia ${ }^{7}$ de alguns recortes de instrumentos de ensinar e aprender disponíveis em rede.

Esses recortes trazem uma memória de como se ensina e de como se aprende a língua na escola e fora dela, de como se usa e de como se compõe um material didático, de como se estabelece a relação entre ensino e tecnologias de linguagem. Uma memória discursiva ${ }^{8}$. Uma memória antes, já lá. Necessária de se compreender em seu funcionamento, na formulação e na circulação dos instrumentos. Também é necessário dizer que no caso desses instrumentos a relação entre memória discursiva também se dá na relação com a memória de arquivo.

Neste caso específico, a compreensão dos recortes ${ }^{9}$ reunidos para a análise se dá com vistas ao modo como as discursividades presentes neles produzem efeitos de sentidos que afetam diretamente a educação, o trabalho em sala de aula e fora dela, a responsabilização do sujeito diante dos discursos do digital cada vez mais presentes na escola e circulantes na sociedade pelo fragmentário da rede.

A multiplicidade desse fragmentário em rede tem início com o desenvolvimento da própria internet no Brasil nos anos 1990. De lá pra cá muita coisa mudou, se multiplicou, se fragmentou. Cada vez mais os

Líng. e Instrum. Linguíst., Campinas, SP, n. 44, p.78-111, jul./dez. 2019 
livros didáticos, as enciclopédias, os dicionários, as gramáticas e as próprias aulas vem sendo transportados e, por vezes, também transferidos para o digital. Para Orlandi (2002) um transporte se dá sem inscrição histórica, na relação palavra-coisa. O transporte se dá por meio de elementos de uma memória linguística, já a transferência é contemplada pelos processos de significação, na relação palavra-palavra, e na perspectiva discursiva, pelos processos de metaforização, conforme nos propõe Pêcheux (1995). Nesse sentido, é pelo trabalho da paráfrase que se pode apreender a metáfora e a compreensão de processos por transferência.

Para a compreensão desse processo de transporte e transferência dos instrumentos linguísticos, na mesma medida em que temos espaços digitais que apenas transportam os instrumentos linguísticos, seja pela reprodução digitalizada de materiais didáticos impressos, seja pela reprodução de atividades que se dão na sala de aula que desconsidera a constitutividade e condições de produção ${ }^{10}$ do digital, temos os que produzem uma transferência, na qual há um movimento de (re)significação, pelo digital, do que seria um espaço de sala de aula. Isso tem efeitos sobre os sentidos de saberes sobre a língua e é para esses efeitos que essa tentativa de cartografia tentará olhar. Vamos aos recortes.

\section{Primeiros Fragmentos: Instrumentos Digitais de Aprendizagem}

Levando em conta que o digital trouxe uma mexida na forma de organização dos instrumentos linguísticos, cabe perguntar pela ordem e pelos efeitos que os fragmentários em rede produzem nos saberes sobre a língua, situando esses instrumentos e o digital na história ${ }^{11}$. Como mostra a História das Ideias Linguísticas no Brasil (HIL), os instrumentos linguísticos conformam o modo como a língua se institucionaliza, como os sujeitos se constituem na/pela língua e suas relações sociais. E é no espaço escolar onde os instrumentos linguísticos mais se mostram nessa relação e nesse processo de institucionalização da língua.

Em suas pesquisas, Pfeiffer (2005, 2007, 2011, et. al.) tem mostrado que a constituição da língua nacional na relação com o espaço escolar, como acontecimento discursivo, produz efeitos de sentidos em que há um lugar possível para o cidadão, portanto para o civilizado, e um lugar outro para o diferente: aquele que deve ser

Líng. e Instrum. Linguíst., Campinas, SP, n. 44, p.78-111, jul./dez. 2019 
INSTRUMENTOS LINGUÍSTICOS E DISCURSOS DE DISPONIBILIZAÇÃO DE/EM INSTRUMENTOS DIGITAIS DE APRENDIZAGEM

\section{instrumentos} LINGÜÍSTICOS

escolarizado. A autora nos aponta em suas análises que há um efeito de coincidência, pela gramatização, entre língua nacional e língua materna, que funciona no espaço escolar.

Interessa, portanto, refletir sobre o funcionamento de discursos que afetam diretamente o espaço escolar, discursos de disponibilização de conteúdos $^{12}$, e o modo como os instrumentos linguísticos se inscrevem nesses discursos em objetos digitais de aprendizagem, um dos nomes dados a esses instrumentos em rede, e que vamos chamar de instrumentos digitais de aprendizagem (IDAs) pela relação com os instrumentos linguísticos, numa análise discursiva, que se inscrevem na história e na memória pelo digital.

Essa nomeação - lembrando que há ainda nomes como: objetos virtuais de aprendizagem, objetos de aprendizagem inovadores, apenas objetos de aprendizagem, objetos educacionais, objetos de aprendizagem interativos, etc - se dá pelos efeitos de sentidos pragmáticos de objeto presentes nas outras nomeações. Nomear instrumentos digitais de aprendizagem se filia teoricamente à análise de discurso, que: 1. toma a noção de materialidade numa perspectiva linguístico-histórica, portanto, discursiva ${ }^{13} ; 2$. tem um modo específico de significar o digital, conforme a pesquisa desenvolvida por Dias $(2004,2014,2016,2018)$; e 3. uma relação com o saber que se dá - ao mesmo tempo - dentro e fora da escola, pela inscrição do digital no urbano, conformando assim um saber urbano (des)escolarizado ${ }^{14}$. Ou seja: um saber contraditório constitutivamente, significado pela individuação do sujeito (ORLANDI, 2012) contemporâneo na relação com o digital, considerando "o digital como constitutivo das discursividades" (ORLANDI, 2015), pensado no movimento dos sentidos dentro e fora da escola simultânea e concomitantemente significado pelo digital e pelo urbano, e não uma retirada dos saberes da escola para inscrevê-la em outro lugar, produzindo o apagamento do político, mas significando os discursos que circulam na escola e fora dela pelo simbólico na relação com o político. Assim sendo, não é possível considerar um virtual em oposição ao real, ou qualquer outra forma de nomear que desconsidere o fato de que não há um fora do digital, de que nossa sociedade é constituída por discursividades digitais. E isso tem seus efeitos nas relações de aprendizagem. 


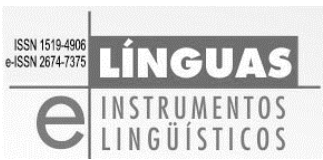

Consideramos que os IDAs estão na relação com um espaço institucionalizado de aprendizagem - a escola - e o fato de que se aprende também fora dela: nas ruas, em casa, no digital. Dizendo de outro modo, a escolha dessa nomeação tem a ver com a noção de um saber urbano (des)escolarizado, constituído pelo digital e que circula dentro e fora da escola. Então, propomos algumas questões ao olhar para os IDAs. $\mathrm{O}$ que muda com um instrumento linguístico na inscrição de uma tecnologia de linguagem pelo digital? Como os discursos de disponibilização de conteúdos afetam os saberes já estabilizados nesses instrumentos? Como gramática e dicionário são significados nesses instrumentos? Quais os efeitos sobre o espaço escolar dessa relação dos IDAs no funcionamento de fragmentação e dispersão tão características do digital?

Estas questões, inicialmente, mobilizarão as análises para a compreensão do funcionamento dos IDAs disponíveis em rede, na sua relação com o espaço escolar. Por isso, analisamos alguns recortes de três repositórios $^{15}$ : o projeto RIVED, o Portal do Professor e o BIOE. O primeiro recorte é do RIVED - Rede Internacional Virtual de Educação, criada em 1999.

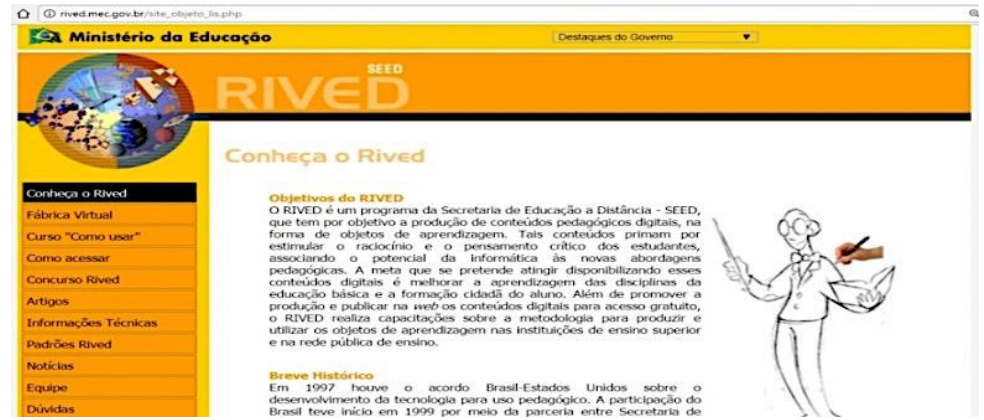

Imagem 1: Conheça o Rived. Print de tela. Disponível em:

<http://rived.mec.gov.br/site_objeto_lis.php〉. Acesso em dez. 2017.

Para viabilizar seu funcionamento, houve um acordo em 1997, entre Brasil e Estados Unidos, cujo objetivo era o desenvolvimento da tecnologia para uso pedagógico, por meio da Secretaria de Ensino Médio e Tecnológica (hoje Secretaria de Educação Básica) e da Secretaria de Educação à Distância - SEED. 
INSTRUMENTOS LINGUÍSTICOS E DISCURSOS DE DISPONIBILIZAÇÃO DE/EM INSTRUMENTOS DIGITAIS DE APRENDIZAGEM

O projeto RIVED tomou forma nessas condições de produção e até 2003 foi SEED responsável pela produção de uma centena de objetos em diversas áreas do conhecimento. Em 2004, o projeto criou a Fábrica Virtual, responsável pela transferência do processo de produção desses objetos para as Instituições de Ensino Superior por meio de uma parceria que ofereceu cursos de capacitação online, pela rede ProInfo, possibilitando a expansão para universidades que passaram à produção e disponibilização de conteúdos na forma de objetos de aprendizagem. Foram produzidos no total 120 IDAs nas mais diversas áreas.

Entre o RIVED, de um lado, e o Portal do Professor e o Banco Internacional de Objetos Educacionais (BIOE) ${ }^{16}$, de outro, ambos desenvolvidos em 2008, pelo Ministério da Educação em parceria com o Ministério da Ciência e Tecnologia, há uma lacuna de 10 anos. Há também uma mudança radical entre a web 1.0 e web 2.0, a web social, como denominou Dale Dougherty, conforme O'Reilly (2005) ${ }^{17}$. As interfaces, os algoritmos e o funcionamento da web mudaram. Percebe-se a alteração significativa de interface entre o RIVED e os outros dois repositórios, as possibilidades de linkagem com outras plataformas e redes sociais, e até a autodenominação do Portal do Professor como uma comunidade, para citar um exemplo de como a web 2.0 modificou estruturas e funcionamentos nestes repositórios. A quantidade de material disponível também sofreu enorme alteração.

Na tentativa de dar visibilidade para essa quantificação de dados e disponibilidade na rede, apresentamos recortes com os resultados de buscas nos três repositórios. No recorte 1, referente ao RIVED destacamos: a) o modo como cada repositório nomeia e define um IDA; b) os objetivos do repositório; c) o modo como o repositório denomina a si próprio e d) a quantidade de IDAs disponíveis em cada um. Vejamos o recorte:

Um objeto de aprendizagem é qualquer recurso que possa ser reutilizado para dar suporte ao aprendizado. Sua principal ideia é "quebrar" o conteúdo educacional disciplinar em pequenos trechos que podem ser reutilizados em vários ambientes de aprendizagem. Qualquer material eletrônico que provém informações para a construção de conhecimento pode ser considerado um objeto de aprendizagem, seja essa informação

Líng. e Instrum. Linguíst., Campinas, SP, n. 44, p.78-111, jul./dez. 2019 
em forma de uma imagem, uma página HTM, uma animação ou simulação. Os objetos de aprendizagem produzidos pelo RIVED são atividades multimídia, interativas, na forma de animações e simulações.

Os IDAs são nomeados como objetos de aprendizagem e, por um processo de reescrituração por expansão (GUIMAR ÃES, 2002) processo no qual o dito é redito permitindo verificar como uma expansão determina outra na temporalidade do acontecimento semântico - são escritos e reescritos como 1 . objetos de aprendizagem; 2. qualquer recurso que possa ser reutilizado; 3 . qualquer material eletrônico e 4. atividades multimídias interativas. Podemos afirmar que os IDAs, nesta discursividade, são determinados como objetos, recurso, material e atividades, sendo predicados por aprendizagem, qualquer e multimídias. Importante notar também a operação de articulação (GUIMARÃES, 2002) - o procedimento permite observar as relações entre as palavras em um enunciado e a relação entre enunciados, considerando enunciado como texto. Tendo isso em vista, gostaríamos de chamar a atenção para uma relação de sentidos estabelecida entre objetos e conteúdo: objetos é reescrito com a "função" de conteúdo e predicado por aprendizagem que é significada como educacional disciplinar.

Esse conteúdo é para ser quebrado e disponibilizado em qualquer meio. São 120 IDAs que passam de objetos a conteúdo disponibilizado e que são ao mesmo tempo - não por sinonímia, mas por expansão e contiguidade - recurso e quaisquer materiais e atividades multimídias.

No Portal do professor vemos:

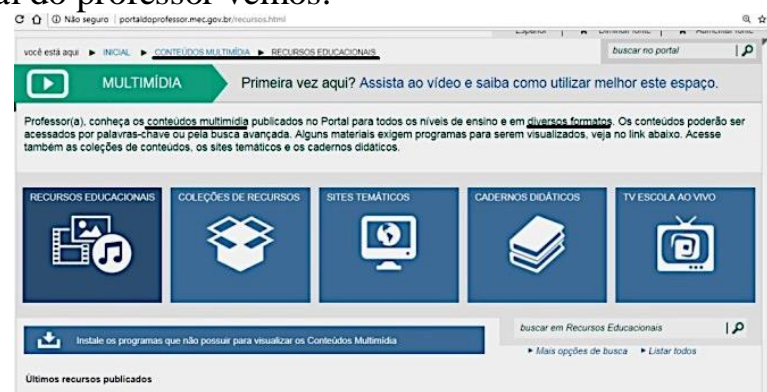

Imagem 2: Print de tela: Portal do Professor > Conteúdos Multimídia. Disponível em: <http://portaldoprofessor.mec.gov.br/index.html>. Acesso em dez. 2017.

Líng. e Instrum. Linguíst., Campinas, SP, n. 44, p.78-111, jul./dez. 2019 
INSTRUMENTOS LINGUÍSTICOS E DISCURSOS DE DISPONIBILIZAÇÃO DE/EM INSTRUMENTOS DIGITAIS DE APRENDIZAGEM

No guia indicador inicial, a nomeação conteúdos multimídias com uma seta para recursos educacionais, e os ícones de acesso são divididos entre recursos educacionais e coleções de recursos que no total chegam ao número de 13.898 IDAs. Esses conteúdos multimídias são predicados pela articulação no enunciado que está no texto ${ }^{18}$ de abertura do site como conteúdos multimídia em diversos formatos, estabelecendo a divisão pragmática entre forma e conteúdo. Chama atenção também nesta divisão que o texto traz coleções de conteúdos e cadernos didáticos, enquanto o segundo ícone da página é nomeado como coleções de recursos estabelecendo pela substituição uma relação de sinonímia entre conteúdos multimídias e recursos educacionais, apagando o político e os sentidos possíveis para o que poderia ser ou não ser educacional. O educacional é determinado pela forma e pelo conteúdo.

Conteúdo, recurso, formato, cadernos: pela diversificação de formatos, os IDAs são organizados e disponibilizados no Portal do Professor. Seja recurso, seja conteúdo está ao alcance de todos, a um clique.

No BIOE, que recebe também o nome de Repositório Educacional, há 19.842 IDAs e o texto de apresentação do site está em três línguas: português, inglês e espanhol. Recortamos para análise a versão em inglês ${ }^{19}$ :

The Educational Repository is an online service for collecting, preserving and providing access to data of research publications and digital content worldwide produced. Enhance your studies, add dynamism to your lessons and conduct your researches with an array of the best-produced digital objects. At the moment, there are 19.842 available objects and 174 are being evaluated or are awaiting their author's authorization to be published. The BIOE hopes to stimulate and foster relevant international relations by democratically leveling up the production and sharing of such Resources. In this sense, countries that have achieved a sound technological progress in education will be able to cope with others. $^{20}$

Este texto diz que o serviço online tem a função de coletar, preservar e fornecer acesso aos dados de publicações de pesquisas e

Líng. e Instrum. Linguíst., Campinas, SP, n. 44, p.78-111, jul./dez. 2019 


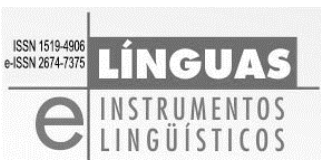

conteúdo digital produzido em todo o mundo. Depois da apresentação, o texto convida o leitor a melhorar seus estudos e pesquisas com os objetos digitais. Num primeiro momento o texto separa dados de publicações de conteúdo digital pelo $e$, mas depois o texto significa tanto um quanto outro como objetos digitais pelo processo de articulação num movimento que homogeneiza o que está disponível no serviço online.

Conteúdo digital é significado como objeto digital. Há uma repetição do que foi observado na análise do recorte 1 . Um IDA pode ser significado como recurso e também como conteúdo digital. A memória da significação recursos permanece nos três lugares. Retomamos a análise feita por Orlandi (2012) sobre a discursividade dos recursos:

Há, quando falamos dos recursos, um dizer já dito e significado que sustenta nosso próprio dizer. $\mathrm{E}$ isto é o que constitui a ideologia em análise de discurso. Quando interpretamos, interpretamos com sentidos já postos, evidentes, e nem sabemos como eles se formaram em nós. Estão lá. Disponíveis. Fazem parte da nossa memória, nosso "saber" discursivo (ORLANDI, 2012, p.148).

E segue apontando para a importância das novas tecnologias de linguagem quando se fala em futuro dos recursos/recursos do futuro. Para a autora, "as novas tecnologias de linguagem representam uma possibilidade de reorganização do trabalho intelectual e do trabalho da interpretação" (idem, p.149).

A nomeação nos diferentes IDAs é distinta, mas os sentidos de recursos permanecem nos três recortes dos distintos repositórios. Esses recursos cumprem o objetivo primeiro de "quebrar", de fragmentar o conteúdo, (RIVED) e depois passam à organização e disponibilização do acesso, no qual há uma transparência dos sentidos para o movimento que pretende tornar claro, legível, bem arranjados e perfeitos como clivagens cristalinas.

Com um fragmentário disponível online, por meio de uma tecnologia de linguagem, os IDAs, se desconsiderada sua materialidade discursiva, pelo funcionamento da ideologia, se 
INSTRUMENTOS LINGUÍSTICOS E DISCURSOS DE DISPONIBILIZAÇÃO DE/EM INSTRUMENTOS DIGITAIS DE APRENDIZAGEM

significam na maioria das vezes como um repositório de objetos organizados e tornados acessíveis àquele que se interessar por saber mais. Mas os saberes estão disponíveis em rede, ao alcance da mão com apenas um clique? São recursos acessados por todos? Faz-se necessário pensar aqui o que diz Orlandi (2012, p.147): "Os recursos são, antes de tudo, recursos humanos”, portanto, são dotados de historicidade, produzidos por "seres sócio históricos, sujeitos simbólicos que se significam e significam o mundo em que vivem”.

\section{Uma busca por fragmentos de instrumentos linguísticos}

Fazendo uma pesquisa por palavras em cada um dos portais analisados é possível observar como a organização deste fragmentário se dá no que diz respeito aos instrumentos linguísticos disponíveis em rede. Em primeiro lugar, as palavras de busca foram língua portuguesa, português e gramática e depois dicionário.

O RIVED (1999) apresentou apenas um IDA, sem data de produção e classificado numa categoria chamada Português e numa subcategoria chamada classe de palavras. Nele há uma indicação de série/ano: primeiros anos do Ensino Médio.

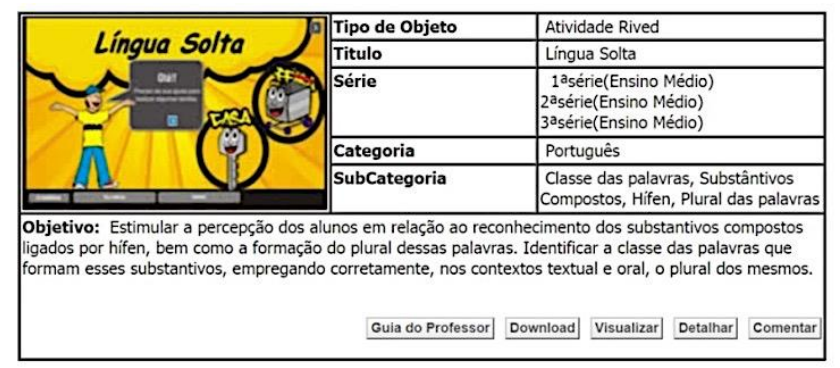

Imagem 3: Primeiro IDA de Língua Portuguesa disponibilizado pelo RIVED (1999).

O Portal do Professor (2008) apresentou como resultado da busca um número de 422 IDAs, produzidos a partir de 2012, das quais apenas 50 são nomeados com referências à gramática. Nesta busca, aparecem os primeiros IDAs que são descritos como objetos que fazem reflexões sobre a linguagem em sua ficha técnica. O BIOE (2008) retornou 483 IDAs, produzidos a partir de 2013, referente à

Líng. e Instrum. Linguíst., Campinas, SP, n. 44, p.78-111, jul./dez. 2019 


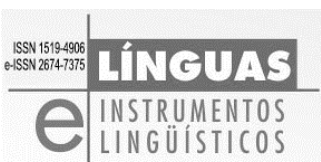

língua portuguesa, português e gramática. Dentre estes, 51 estão relacionados à gramática e dois são descritos como objetos na categoria historicidade da linguagem.

Tanto no Portal do Professor, como no BIOE, os resultados de objetos com reflexões sobre a linguagem se repetiram. Nos três portais, a categoria gramática está presente. Apesar de a busca não retornar resultado algum para a palavra gramática em específico no RIVED, é possível a compreensão da presença de organização gramatical na subcategoria classe de palavras.

No Portal do Professor e no BIOE, as buscas resultaram em centenas de objetos que não estão mais categorizados como português, contudo apresentam referências a reflexões sobre a linguagem em sua descrição e dezenas deles com referências à categoria gramática. Deste resultado, dois objetos do BIOE apresentam formulações referentes à historicidade da linguagem, mostrando aí os efeitos do trabalho com os instrumentos linguísticos no interior da produção do saber metalinguístico e de todo avanço da própria linguística como ciência que reflete seu próprio objeto.

A pesquisa seguinte foi pelo termo dicionário. Não há dicionários como resultados de busca no RIVED. Também não há dicionários disponíveis em outros lugares de disponibilização de IDAs, mas apesar disso, há enciclopédias e há também reflexões sobre o papel do dicionário, sua importância e utilização ${ }^{21}$.

Diante dessa reflexão e do (não) resultado que é possível encontrar nas buscas, os lugares de disponibilização de IDAs, a partir desses repositórios, se colocam como um lugar do discurso sobre o dicionário, de destaque de sua importância e sobre seu aspecto utilitário. Enunciados como: reflexões sobre o dicionário, importância do dicionário como instrumento linguístico e reflexões sobre políticas linguísticas estão tanto no Portal do Professor quanto no BIOE. O aspecto utilitário do dicionário também está nos dois lugares com as palavras: ensinar, explicar sobre, orientar e explicar o uso correto.

Essas plataformas produzem um saber sobre o dicionário, elas não o disponibilizam simplesmente como instrumento linguístico digital. Isso ficará a cargo de outras plataformas, como o Google Dicionário, por exemplo, e que não será objeto de análise neste momento, mas que poderia ser, dado o seu funcionamento como instrumento digital de aprendizagem. Com esse fato da não disponibilização do dicionário nestas plataformas, ao contrário de outros instrumentos como a

Líng. e Instrum. Linguíst., Campinas, SP, n. 44, p.78-111, jul./dez. 2019 
gramática, o dicionário ganha um lugar imaginário de homogeneidade e organização unitária na rede e não de dispersão. Não uma organização unitária como foi a partir do códex, em que temos o limite de um número de verbetes em uma quantidade de páginas específicas. No caso do Google Dicionário, a visualização se dá verbete por verbete e na ilusão de uma quantidade sem fim de definições e palavras disponíveis.

Com esses recortes, compreendemos que os IDAs estão neste lugar fragmentário de dispersão e isso tem efeitos. O que chama a atenção é o modo como em três diferentes lugares, a princípio, os IDAs são (re)significados como recursos educacionais. Retomando o que diz Orlandi (2012, p.145) sobre os discursos que falam sobre recursos, há aí uma inscrição no discurso empresarial "fortemente atado à ideia de "informação" que projeta um público alvo de coisas-a-saber (PÊCHEUX, 2014).

No caso desta análise, são recursos educacionais. Recursos de e para sujeitos inscritos na discursividade educacional, na relação com instrumentos linguísticos. Vale lembrar também o que Orlandi (2001) ressalta a respeito dos instrumentos linguísticos na relação com o ensino:

Quando refletimos sobre a presença desses instrumentos na escola [...] não se trata de pensar o mero uso de um artefato mas da construção de objetos históricos. [...] Não falamos, então, dessa perspectiva, na função da gramática ou do dicionário na escola mas do funcionamento deles na relação do sujeito com a sociedade na história (ORLANDI, 2001, p.8).

Portanto, essa relação do sujeito com a sociedade na história, considerando a contemporaneidade, está inscrita no digital que tem seu modo de funcionamento específico. O IDA, portanto, é significado como tecnologia de informação pelo digital.

Para refletir sobre as tecnologias de linguagem no digital é importante considerar o que afirma Dias (2016) sobre o modo como o digital tem modificado a discursividade do mundo através de um processo que a autora tem chamado de digitalização do mundo, qual seja: 


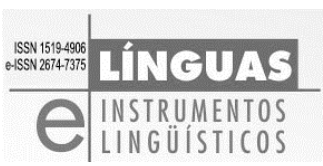

práticas de linguagem que tendem à metaforização das relações sociais e das práticas dos sujeitos [...]. Em outros termos, a digitalização do mundo é um processo de historicização dos sentidos que desloca o modo de significação, produzindo uma forma material (DIAS, 2016, p.10-11).

Assim, dizer de IDAs é dizer de uma forma material específica que circula na sociedade, para além do espaço escolar e não apenas, como fragmentos de saber como meros conteúdos pragmáticos, quebrados e estilhaçados, como quando um cristal toca o chão.

\section{Segundos Fragmentos: redes sociais de aprendizagem}

Assim como os arranjos cristalinos se agrupam e se reagrupam, poderíamos pensar os instrumentos digitais de aprendizagem com sentidos que circulam também nas redes sociais nesse movimento de organização. Entretanto, a ordem dos sentidos não é da mesma ordem dos cristais, ou do vidro. Antes, essa ordem é muito menos apreensível como objeto lógico e, por estar na relação entre história, ideologia e inconsciente, é uma ordem que não se coloca de modo prático e transparente. Portanto, buscando a compreensão dessa ordem dos sentidos, a análise neste subtítulo será sobre o funcionamento de redes sociais de aprendizagem, que tomamos também como IDAs, na relação com a memória discursiva e a memória metálica.

As redes sociais de aprendizagem não se nomeiam nem se definem como instrumentos digitais de aprendizagem, mas se colocam como lugares depositários de um saber, ou melhor dizendo, como lugares depositários de objetos - produtos - para, enfim, disponibilizá-los em rede, significando-se como lugar de saber, lugar de objetos do saber, lugares possíveis para fazer circular esses saberes em formas de objetos.

Considerando as condições de produção do discurso pedagógico na chamada era da informação, pelo funcionamento das redes, de sua configuração de interface, por meio de uma cartografia políticoideológica do espaço digital (Dias, 2004), os saberes disponibilizados na contemporaneidade no digital estão significando um espaço importante de reflexão sobre a linguagem: a escola.

Partindo desta premissa, apresentamos a rede social educacional edmodo $^{22}$ (com letras minúsculas em sua plataforma). Disponível em

Líng. e Instrum. Linguíst., Campinas, SP, n. 44, p.78-111, jul./dez. 2019 
inglês, francês, espanhol, português, grego e alemão, a rede recebeu, em 2011, o prêmio de melhor site da web para ensino e aprendizagem da AASL - American Association of School Librarians e venceu na categoria Education \& Reference o Webby Award, em 2012, quatro anos após sua criação e na categoria Community, em $2014^{23}$. A rede edmodo apresenta parceria com a Microsoft para o uso de ferramentas do Office 365 e com o Google for Education, que será objeto de análise na próxima seção.

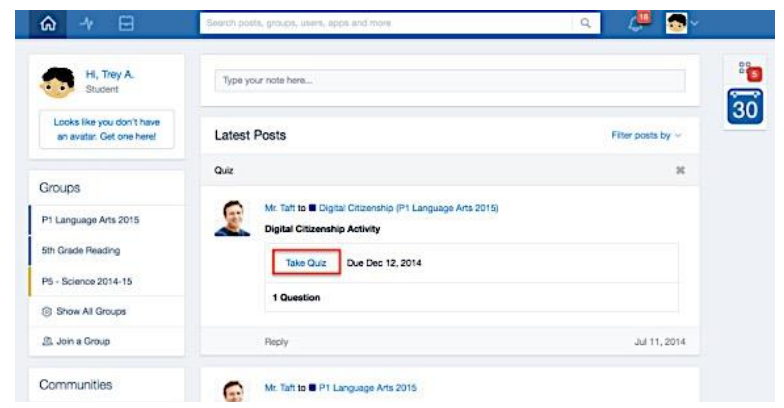

Imagem 4: Print de tela da rede social edmodo. Disponível em: https://goo.gl/kUFmbR. Acesso em dez. 2017.

A rede social edmodo se apresenta com uma interface semelhante à da maior rede social na contemporaneidade: o Facebook. A disposição dos elementos na página, a escolha das cores, a distribuição do mural de notícias no centro da página, dos grupos ao lado esquerdo, da foto de perfil e das notificações no topo retomam a memória de estrutura e funcionamento do Facebook. Contudo, a rede difere por não ser aberta a qualquer assunto para postagem e nem a qualquer público, se limitando à comunidade escolar, professores e alunos.

Em 2008, quando a edmodo começou suas atividades, ainda numa versão inicial, o slogan de abertura era The free communication platform for education ${ }^{24}$. Ou: A plataforma de livre comunicação para a educação. Neste primeiro recorte, a indagação se dá por uma compreensão da configuração da plataforma como instrumento e como ferramenta que se coloca no lugar que possibilita a livre comunicação. A plataforma se apresenta como lugar de livre comunicação, em contraponto, a escola, a sala de aula, a aula, não o é? Nem lugar de liberdade, muito menos de comunicação? A sala de aula 


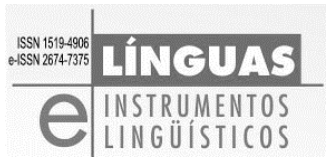

muitas vezes é significada como o lugar onde o professor fala e o aluno ouve, o lugar do silêncio - ou melhor dizendo - o lugar do silenciamento, conforme o conceito de silêncio desenvolvido por Orlandi (2007a).

$\mathrm{Na}$ aula, o aprendiz de uma educação depositária, tomando aqui de empréstimo uma formulação freiriana, não é livre para comunicar e o professor que muitas vezes tem que seguir parâmetros curriculares e determinações de instâncias superiores também não comunica o que quer. A ilusão de liberdade determina o espaço escolar. E o espaço da rede? Uma vez que alunos e professores se encontram já significados na dispersão fragmentária do digital, é necessário questionar os efeitos de liberdade colocados pelas redes. As redes também produzem silêncios. Ou ainda, como afirma Dias (2018) há uma dimensão técnica do silêncio nas redes.

Se a educação está significada como lugar onde a comunicação nunca foi livre, há a necessidade de uma plataforma para livre comunicação. Isso implica também perguntar: em outras plataformas a comunicação não é livre? Que possibilidades há de liberdade em plataformas, redes, repositórios? Ou ainda: fora da educação, a comunicação é livre?

Uma outra imagem ${ }^{25}$ que abre a rede social edmodo afirma que a rede tem 20 maneiras de usar. Se há 20 maneiras de usar a rede social, podemos retomar questionamentos sobre a liberdade diante da dispersão dos saberes disponíveis em rede. Porque uma limitação numérica tão grande (e tão pouca) perante a imensidão do digital? A plataforma é de livre comunicação, mas as maneiras de usar são limitadas ao número 20. O número dos dedos que digitam considerando os sujeitos dos dois lados da tela? Limitação do sujeito, da rede, da liberdade? O que se limita ao colocar numericamente contável nos dedos das mãos os modos de usar?

Para avançar um pouco mais na reflexão, propomos ainda uma terceira formulação de abertura da rede: Faça da sua sala de aula uma comunidade. A rede edmodo limitada ao uso digital, ou das 20 digitais dos sujeitos, não apresenta limitações quanto à liberdade. É livre. A quem adere resta apenas fazer de sua sala de aula a comunidade que ela não é. Agora, resta perguntar quais são os sentidos para comunidade: sentidos de pertencimento, de algo do qual se faz parte pela rede e do qual não se fazia antes? Através do uso de uma 
INSTRUMENTOS LINGUÍSTICOS E DISCURSOS DE DISPONIBILIZAÇÃO DE/EM INSTRUMENTOS DIGITAIS DE APRENDIZAGEM

plataforma, é possível transformar a sala de aula naquilo que ela supostamente nunca foi: uma comunidade.

O professor, cercado de propostas de compartilhamento do saber em rede, filia-se a uma discursividade de obsolescência da escola, que não é digital, que não é limitada ao uso de apenas 20 maneiras, e a uma discursividade sobre o revisionismo de suas práticas; assim, o ensino busca uma reconfiguração em sua formulação.

Portanto, a rede social educacional se coloca como esse lugar depositário dos saberes disponíveis e como espaço de significação de um lugar de saber e não mais na dispersão de materiais possíveis para a aprendizagem, mas na unificação do que puder ser disponibilizado no digital e compartilhado em rede. Estão lá, nas redes sociais de aprendizagem, os IDAs disponíveis, compartilhados e curtidos por todos. Todo o saber em um só lugar que é configurado como espaço de saberes.

\section{Terceiros fragmentos: Google for Education ${ }^{26}$}

Muitas instâncias da vida social hoje estão permeadas pelo digital. $\mathrm{O}$ investimento em aparatos tecnológicos, tanto pelo poder público quanto pelos próprios cidadãos, que vai desde a infraestrutura de internet até a aquisição de celulares/smartphones, faz parte das necessidades e investimentos básicos da vida, tais como saneamento, moradia, alimentação, lazer e educação. Isso faz com que as relações sociais sejam significadas na e pela linguagem do digital, através do uso da Internet como espaço de (des)legitimação de sentidos e até do estabelecimento de novas categorias de relação no tempo e no espaço da cidade e nas redes de colaboratividade online como uma extensão do que se pode chamar espaço real, afetando a sociedade no que diz respeito tanto ao seu modo de organização, estruturação, funcionamento, bem como a educação.

É cada vez mais frequente o uso de plataformas e recursos tecnológicos disponíveis em rede, tornando a internet também um espaço para um saber urbano (des)escolarizado, um saber que se constitui dentro e fora do espaço escolar, no espaço digital que é urbano constitutivamente, que é perpassado pelas redes de colaboratividade e compartilhamento de conhecimento, nos livros e bibliotecas tanto impressos quanto digitais. Tomamos o Google for Education como um instrumento digital de aprendizagem para

Líng. e Instrum. Linguíst., Campinas, SP, n. 44, p.78-111, jul./dez. 2019 
compreender o funcionamento da circulação de saberes na relação com a educação no espaço da cidade e da rede.

A tarefa é analisar essa dispersão que se coloca pelo que se denomina como Google for Education, buscando estabelecer relações entre o que move a sociedade pela linguagem e o que se coloca no digital. O modo de nomear uma ferramenta de tecnologia digital e de significá-la por meio de uma relação apositiva num enunciado nos dá elementos para compreender esse objeto como instrumento digital de aprendizagem do modo como estamos olhando para esses dispositivos analíticos. O funcionamento do nome próprio e do aposto circula e produz efeitos de sentidos na e para a sociedade em que está inserida, em uma proposição que significa em sua circulação e traz questões para o que interessa à educação e aos sentidos produzidos pelo seu funcionamento na sociedade.

A circulação dos sentidos para "Google for Education: uma solução desenvolvida para professores e alunos", com seu nome e seu aposto, faz com que se pergunte pelo político nessa relação entre professores e alunos permeada pelo digital. Uma plataforma? Um repositório? Como o Google for Education está se significando e sendo significado? Tomando a palavra Google como um primeiro recorte, é possível afirmar que ele nomeia um site de busca na internet, mas também uma empresa, e até funciona como verbo "googlar/ dar um google" em alguns casos. No caso específico da nomeação analisada, ela nomeia e destina uma ferramenta para um público específico, e por meio de seu aposto apresenta uma solução através de aplicativos para a educação.

Antes de tudo, há que se refletir sobre alguns sentidos possíveis para o nome próprio Google: uma empresa, um motor de busca na internet, uma ferramenta completa que soluciona problemas na educação, um guru que a tudo nomeia, responde e dá existência. Depois, para pensar o que estaria em jogo na significação desse nome - Google - é necessário buscar na formulação do enunciado o funcionamento da preposição a que e a quem ele se destina, pois nessa análise, não se tratará do Google como um todo ou do Google enquanto empresa, mas de uma de suas plataformas que é for Education, pois há outras ferramentas oferecidas pelo Google: Drive, Mapas, Tradutor, Notícias, Acadêmico, Imagens, Gmail, Youtube, Agenda, Google+, Pesquisa, Docs, etc ${ }^{27}$.

Líng. e Instrum. Linguíst., Campinas, SP, n. 44, p.78-111, jul./dez. 2019 
INSTRUMENTOS LINGUÍSTICOS E DISCURSOS DE DISPONIBILIZAÇÃO DE/EM INSTRUMENTOS DIGITAIS DE APRENDIZAGEM

A pergunta por este funcionamento do nome numa materialidade aponta para sujeitos em posição de determinar as relações que constituem a educação pelo digital. Seguido ao nome próprio, um enunciado em relação apositiva apresenta o Google for Education como uma solução na relação entre professores e alunos, colocando a possibilidade de múltiplos sentidos. Assim, as análises que seguirão buscarão compreender como, por meio de um instrumento digital de aprendizagem, os sujeitos estão em posição de determinar como se deve dar a educação, significada por um espaço peculiar de produção dos sentidos: o digital.

\section{Google para quê; Google para quem?}

$\mathrm{Na}$ página inicial do aplicativo educacional oferecido pela empresa Google temos a seguinte formulação: Google for Education: uma solução desenvolvida para professores e alunos. Uma sociedade privada, administradora de um dos mais populares motores de busca do mundo cujo nome próprio é o mesmo. Um nome próprio ${ }^{28}$ e um aposto. Um enunciado, um texto. Um espaço de enunciação: o digital. Google empresa, Google aplicativo, Google site de busca. Coincidência no nome que coincide também com a própria internet e que para milhões de usuários diante da internet é, todavia, no Google que se produz efeitos. Ainda que o Google seja um motor de busca dentre outros, Cassin (2008) mostra que faz parte da estratégia do portal ser proprietário de toda a informação e conduzir os usuários a outros sites, produzindo esse efeito de coincidência entre Google e Internet. Efeito esse da Internet como

um mundo bem mais deleuziano, uma estética suportesuperfície sobre um fundo de cérebro-máquina: rede, rizoma, centro em todas as partes, circunferência em nenhum lugar, multiplicidades, subsidiaridades, potências diretas da multidão, simplicidade de conexão, auto-organização... Um mundo feito por todos, em imanência, e não por um (CASSIN, 2008, p.21).

O nome próprio Google for Education, pelo funcionamento da designação, significa na relação com o motor de busca Google, com a empresa de mesmo nome e com o próprio efeito de coincidência com a Internet. Surge na enunciação como um acontecimento de linguagem na relação com o simbólico e com a história ${ }^{29}$. Os sentidos não estão 


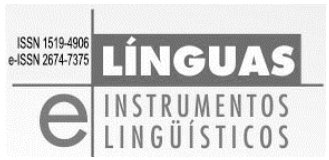

prontos e acabados, estão sempre se (re)construindo no movimento constante do simbólico e da história.

O nome próprio Google apresenta um funcionamento que significa pelo processo de designação. Ao dizer Google, há um recorte no espaço da memória discursiva, que remete a vários sentidos já colocados pelo funcionamento do dispositivo digital. Google significa na relação com o site de buscas na internet, com um funcionamento algorítmico determinado, específico e secreto, que faz com que os resultados das buscas estejam ligados a um perfil de usuário por meio de filtros personalizadores de cada experiência na rede. Ao se colocar em um lugar social de locutor, o Google já está determinado pela história com seu efeito de sentido de coincidência com a Internet e como aquele que a tudo responde, que tudo sabe, que tudo nomeia.

É bastante comum atualmente, formandos de cursos diversos, principalmente de Ensino Médio, utilizarem uma camiseta personalizada com enunciados sobre este momento significativo em seu percurso escolar. Uma das imagens bastante utilizada nessas estampas traz o seguinte enunciado: Gostaria de agradecer aos meus pais, meus amigos e principalmente ao Google. $\mathrm{O}$ personagem caracterizado como um formando traz a memória do funcionamento do meme em redes sociais $^{30}$. O enunciado traz a memória do Google como aquele que tem resposta para todas as questões, que ensina, que forma. Assim, a relação Google site de busca e Google no contexto educacional se mostra forte e constitutiva de sentidos e sujeitos no e pelo espaço digital. Ao fazer uma busca no Google, pelo aplicativo Google for Education, os resultados são apresentados também com o nome do aplicativo seguido do enunciado apositivo: uma solução desenvolvida para professores $e$ alunos.

Observando o enunciado no aposto é possível afirmar que aquele que enuncia, que está no lugar social de locutor é o próprio Google, e este se coloca em posição de ser uma solução. Uma solução para professores e alunos colocados em posição daqueles que, neste caso, são os que precisam de auxílio, que não são dotados de saber, que estão em formação constante, em posição embrionária do vir a ser. O locutor Google é a solução; os professores e alunos, parte do problema. 
INSTRUMENTOS LINGUÍSTICOS E DISCURSOS DE DISPONIBILIZAÇÃO DE/EM INSTRUMENTOS DIGITAIS DE APRENDIZAGEM

- instrumentos

- LINGÜÍSTICOS

\section{Tecnologia no tempo}

A palavra tecnologia, considerando a acepção que a toma como derivada do grego $\tau \varepsilon \chi v \eta$ (técnica, arte, ofício, estudo), é uma palavra que relaciona conhecimento técnico e científico através do uso de ferramentas, processos ou materiais criados a partir de tal conhecimento.

As tecnologias de escrita e leitura são desenvolvidas no percurso da própria história, no tempo e no espaço, se relacionando com as sociedades em que surgiram, alterando-se modos e sistemas de viver. $\mathrm{E}$ ao analisarmos a palavra solução no enunciado apositivo a colocamos em relação com a tecnologia e a materialidade histórica do real, afetada pelo simbólico. A enunciação aqui não é resultado de um ser físico, no mundo físico, mas é antes o dizer do sujeito nesta materialidade do real ${ }^{31}$.

A enunciação que considera a tecnologia presente, enquanto acontecimento de linguagem, no qual todo acontecimento de linguagem significa porque traz em si mesmo uma projeção de futuro. $\mathrm{O}$ presente e o futuro próprios do acontecimento funcionam por um passado que os faz significar como ferramentas substituíveis para antigos problemas. Uma solução. Tecnológica, por meio de um nome próprio que significa para a educação, for Education.

Sendo assim, o Google for Education se apresenta com uma diferenciação importante de outras ferramentas do Google pelo funcionamento da preposição for, para, com um sentido de destinação específica deste produto. Esse nome próprio chama a atenção e mostra o seu aspecto de instrumentalização - não é Google educacional, Google escolar, Google Educação Básica, uma vez que já há outro produto com o nome Google Acadêmico. É Google for Education. Em 190 países e 50 milhões de usuários. É um Google para, palavra que determina o destino dessa aplicação, ao contrário de outros lugares em que o Google se enuncia Sobre os ombros de gigantes, como é o caso do Google Acadêmico: um serviço de busca do Google que permite buscas em pesquisas científicas, acadêmicas, lançado em 2004 e que até 2014 pretendia cobrir $85 \%$ de todos os textos acadêmicos já publicados e disponíveis em rede. ${ }^{32}$

Desta posição, o locutor se apoia naqueles que significam o saber científico, o acadêmico, está apoiado, está sobre os ombros, em contraponto com aqueles que apresentam problemas: professores e alunos; e o Google se apresenta como solução para a educação. Na

Líng. e Instrum. Linguíst., Campinas, SP, n. 44, p.78-111, jul./dez. 2019 


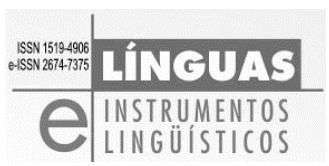

academia, gigantes, apoiadores. Na educação, problemas a serem solucionados. Campos de significação dados pelo digital que coloca questões para essas relações tão tênues. A preposição no Google Acadêmico é sobre, não mais para como no Google for Education.

A designação for Education aponta para um sentido já dado de educação. Pronto e acabado. O sentido da educação formal, institucional. Desse modo, o nome próprio Google é para todos, mas esta materialidade específica é para a educação e se apresenta como aquele que vai sanar os problemas.

Ao dizer apositivamente que é uma solução desenvolvida para, há o funcionamento de um pré-construído de que há um problema que precisa de solução e a formulação se torna equívoca: uma solução para um problema que professores e alunos têm ou uma solução para o problema que professores e alunos são? Sendo for Education este aplicativo é designado como aquele que vai sanar os problemas de professores e alunos, da escola ou vai sanar os problemas que são professores e alunos. Quais os sentidos de educação nesse nome? Uma educação com problemas que precisam ser resolvidos? Uma educação possível a partir do uso do Google? Esses são questionamentos que precisam ser feitos a esses instrumentos que se colocam no contexto educacional atual configurando sujeitos e sentidos, reformulando processos e práticas, significando pela língua a história da tecnologia.

Os sentidos de tecnologia no passado, sendo desconsiderados, produzem um efeito de apagamento da própria história dos materiais, ferramentas e processos de aprendizagem. Antes do advento tecnológico que temos hoje, tínhamos uma relação professor-material didático-aluno e que produzia como efeito um aluno $\mathrm{X}$. Na nova relação proposta pelo intermédio do aplicativo tecnológico, temos uma relação aplicativo-aluno e a produção de aluno $\mathrm{Y}$ como efeito. Um aprender outro, na relação com a máquina, com a memória metálica (ORLANDI, 2007b), numa substituição lenta e progressiva do professor e seu antigo material didático que, embora não mude o nome aluno, muda-se a relação entre os sujeitos e os instrumentos aí envolvidos. Instrumento, meio e fim. A relação antes era entre sujeitos e instrumentos linguísticos e passa a ser entre um sujeito e um tipo de instrumento específico.

Numa análise das mediações que acontecem na relação de aprendizagem na escola, Orlandi (1983) diz que o livro didático sendo

Líng. e Instrum. Linguíst., Campinas, SP, n. 44, p.78-111, jul./dez. 2019 
INSTRUMENTOS LINGUÍSTICOS E DISCURSOS DE DISPONIBILIZAÇÃO DE/EM INSTRUMENTOS DIGITAIS DE APRENDIZAGEM

usado de modo a cumprir um fim determinado acaba por apagar seu caráter mediador estabelecendo a relação autoritária entre o professor que repassa um conteúdo ao aluno. A autora enfatiza que o material didático deveria ser produzido pelo professor em conjunto com o aluno e que um material pronto pressupõe um aluno pronto.

$\mathrm{Na}$ discursividade do enunciado analisado há uma proposta de substituição do professor por instrumentos digitais de aprendizagem, pois se o Google for Education, que estamos significando aqui como um dos IDAs possíveis, é a solução tanto para professores quanto para alunos, isso não é sem efeitos. A sociedade hoje se constitui pelo digital, ou, como dito por Orlandi (2015), "o digital é constitutivo das discursividades", ou seja, por uma digitalização do mundo definida por Dias (2016) enquanto "práticas de linguagem que tendem à metaforização das relações sociais e das práticas do sujeito que, por meio do 'livre' acesso, deslocam o campo da 'luta' para uma inscrição na forma digital", e na formação discursiva da Sociedade da Informação, desta que está na injunção de significar pelo aspecto comunicacional informativo, pelo acúmulo exponencial dos saberes tomados como informação pelo funcionamento da memória digital.

Portanto, o que se estabelece no funcionamento do nome próprio e do aposto não é uma mera relação entre coisa-palavra, mas uma relação semântico-discursiva enquanto prática política, que faz funcionar o político e um apagamento na formulação equívoca do nome Google, produzindo efeitos de sentido que nos fazem perguntar sobre esses novos dispositivos que se colocam. Para quê e para quem? $\mathrm{Na}$ transparência dos sentidos, o acesso e a cidadania se constituem como lugares perfeitamente alcançáveis por todos sem que se pergunte pelas diferenças existentes em nossa sociedade.

Assim, a questão do acesso é o que se coloca como espaço de disponibilização dos saberes (e das soluções) que podem resolver problemas para professores e alunos. Um recurso de aprendizagem, uma solução por meio de um discurso de acesso, de disponibilização e por meio de uma unidade que conjuga a dispersão constitutiva do digital.

\section{Fragmentos espalhados - olhares a distância}

Diante das múltiplas possibilidades de materiais para análise, e da impossibilidade de atingir a completude, sempre temos que delimitar, 


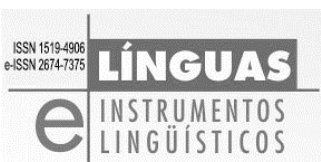

recortar, estabelecer um limite para o objeto de pesquisa, no tempo e no espaço das materialidades possíveis. Consideramos assim a materialidade digital como espaço constitutivo de discursividades que circulam na sociedade de/para e por sujeitos, conforme Dias (2004) tem abordado em suas pesquisas no Brasil as questões pertinentes à Análise do Discurso Digital.

Os discursos analisados, textualizados na materialidade digital, constituem processos de significação para sujeitos em posição de ensinar filiados a uma rede social digital educacional, que conforma um instrumento digital de aprendizagem para organizar suas aulas. Refletindo sobre os processos de significação, buscamos compreender a constituição, formulação e circulação desses discursos. Essa configuração se deu pela busca em compreender de que modo as chamadas novas tecnologias estão relacionadas com um certo modo de significar as práticas educativas em dois espaços constituídos pelo urbano e o digital: a escola e a cidade.

O gesto que fazemos é olhar para o que circula na internet, para os discursos de sujeitos atravessados pelo funcionamento do digital e também para esse espaço de significação de educação que ali se apresenta. A compreensão de que não há discurso sem sujeito e nem sujeito sem ideologia (ORLANDI, 2008) é fundamental para que se possa fazer um gesto de interpretação de redes específicas rede/cidade que passam a compor um corpus heterogêneo e diversificado em sua materialidade, que dão forma a este trabalho significado por suas relações de sentido, sempre abertas e marcadas em sua forma linguístico-histórica pela incompletude.

Ao tentar reunir estes recortes, nesta dispersão e incompletude, pudemos perceber alguns movimentos que significam discursos sobre educação hoje, especificamente sobre reformas no Ensino Médio, atravessados por essa historicidade, por esse fragmentário e pelos efeitos do digital.

No ano de 2016, tivemos no Brasil uma medida provisória de Reforma do Ensino Médio propondo que o ensino seja em tempo integral, dentre outras mudanças. No começo de 2018, o Conselho Nacional de Educação começou a discutir a proposição de $40 \%$ das aulas do Ensino Médio ser à distância ${ }^{33}$ e posteriormente intensificou-se a discussão sobre a liberação de educação domiciliar.

Líng. e Instrum. Linguíst., Campinas, SP, n. 44, p.78-111, jul./dez. 2019 
INSTRUMENTOS LINGUÍSTICOS E DISCURSOS DE DISPONIBILIZAÇÃO DE/EM INSTRUMENTOS DIGITAIS DE APRENDIZAGEM

No mesmo ano de 2016, a CAPES lançou o portal EduCAPES ${ }^{34}$. Um "portal de objetos educacionais abertos", conforme a descrição do site, que disponibiliza não apenas os chamados recursos educacionais, mas todos os links de empresas com as quais há parceria públicoprivada. Da Educação Básica à Pós-Graduação, com a disponibilização de IDAs tanto do BIOE e Portal do Professor até material da UAB - Universidade Aberta do Brasil, que oferece diversos cursos $\mathrm{EaD}$ e artigos científicos disponibilizados nos repositórios de universidades brasileiras. Material disponível não falta. Organização também não. Então o que poderia faltar, falhar? O que é necessário para que a educação fique melhor? Como fazer chegar saber(es) até sujeitos que não conseguem ter acesso a ele(s)? Esses sujeitos à margem querem ou necessitam desse(s) saber(es)? O/No discurso da disponibilização de conteúdos não se faz questão desta ordem, antes se filia a uma discursividade do tudo ao alcance de todos. Só não sabe quem não quer... (?)

A reflexão proposta - acerca dos fragmentários dispersos na rede como tecnologias de linguagem, possíveis de usos por sujeitos filiados às condições de produção educacionais - se direciona agora para a questão social. Retomando o fato de que já na formação da primeira rede - o RIVED - a Secretaria de Ensino Médio e Tecnologia juntamente com a Secretaria de Educação a Distância estavam unidas trabalhando na construção dos objetos ainda virtuais de aprendizagem, mesmo sem a web social, sem os discursos de obsolescência e precarização, e consequente entrega nas mãos da privatização, tão fortes como nos últimos tempos. Hoje temos o Google for Education fazendo convênios com Secretarias Municipais e Estaduais em todo país, fornecendo notebooks, e várias outras empresas amigas da escola fornecendo suportes, instrumentalizando, sustentando a estrutura e desresponsabilizando o Estado.

Esses discursos de obsolescência da escola, da precariedade da escola e da infraestrutura de redes que temos no país, preconizam a justificativa de formação constante dos professores e a necessidade urgente de modernização das tecnologias de ensino aprendizagem. Os sujeitos-professores muitas vezes são responsabilizados por sua formação e pela falta dela.

Com o digital, os modos de aprender e de ensinar se reconfiguram constituídos pela busca desses sujeitos nas redes digitais, uma vez que,

Líng. e Instrum. Linguíst., Campinas, SP, n. 44, p.78-111, jul./dez. 2019 


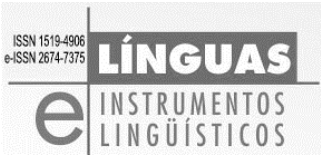

pela constituição do digital na sociedade contemporânea, há outros modos de subjetivação dos sujeitos. Assim, é necessário considerar a opacidade dos sentidos do ensinar e aprender em rede, por meio dos modos de organização do saber no digital, e compreender a cartografia das redes de aprendizagem enquanto um espaço do possível, onde sujeitos e sentidos podem ser outros. Mesmo os que estão à distância de alcançar o acesso a tudo isso.

\section{Recolhendo os cacos}

Areia. Sílica. Silício. Do Silicon Valley, na Califórnia, ao Silicon Wadi, em Israel, a metáfora do cristal mais abundante do planeta serve de nomeação aos maiores conglomerados produtores de tecnologia do mundo. E ela se espalha. Por estar muito presente em nosso cotidiano, não nos damos conta, nem do minério, nem da tecnologia. Transparências pelas quais não nos perguntamos. Aceitamos. Contudo, aceitamos sem conhecer. Sem saber usar, sem saber quem determina o que, sem poder de decisão, numa ordem intacta do estabilizado.

Estamos diante de uma possibilidade de transformação sem precedentes na história das tecnologias de linguagem, de ressignificação dos instrumentos linguísticos e do ensino da língua, de organização da escola que se dá nela e fora dela. Uma organização pelo digital que coloca a própria instituição tal como é conhecida em questão. Seria possível a configuração de IDAs de tal modo que a "obsolescência da escola" possa ser "superada" e a aprendizagem formal se dê apenas por espaços digitais? Nessa hipótese, como repensar o que conhecemos por séculos como "educacional", como escola? O saber não é intrínseco às instituições, à escola, ou a um lugar no digital.

Essa reorganização pela constitutividade da sociedade que é digital coloca questões (que este texto não tem a pretensão de responder, mas problematizar). E essas questões passam pela divisão social que se coloca quando uns têm acesso e outros não, quando interesses de mercado atravessam os interesses educacionais, quando o saber se torna moeda de troca e não está num lugar possível para trocas. Com a constituição da sociedade pelo digital, com o urbano atravessado pelo digital apagando as fronteiras antigas do online/off-line, do aprender na escola e fora dela que já não existem mais, precisamos ao menos nos atentar para o simples fato

Líng. e Instrum. Linguíst., Campinas, SP, n. 44, p.78-111, jul./dez. 2019 
INSTRUMENTOS LINGUÍSTICOS E DISCURSOS DE DISPONIBILIZAÇÃO DE/EM INSTRUMENTOS DIGITAIS DE APRENDIZAGEM

de que lemos este texto sem nos darmos conta de que sua escrita só foi possível graças ao cristal. Fragmentado. Da Califórnia a Israel para o mundo todo em microchips de areia. O que mais será possível?

\section{Referências Bibliográficas}

AUROUX, S. (1992). A Revolução Tecnológica da Gramatização. Campinas: Editora da Unicamp.

BRANCO, P. de M. (2008). Dicionário de Mineralogia e Gemologia. São Paulo: Oficina de Textos.

CASSIN, B. (2008). Googléame: la segunda misión de los Estados Unidos. Buenos Aires: Fondo de Cultura Económica: Biblioteca Nacional.

COELHO, C. G. F. (2016). Discursos sobre a leitura no Brasil: dos documentos oficiais e do livro (no)digital. Campinas: [s.n.]. Dissertação de Mestrado em Linguística - Universidade Estadual de Campinas, Instituto de Estudos da Linguagem.

DIAS, C. (2004). A Discursividade da Rede (de sentidos): a sala de bate-papo hiv. Campinas: [s.n.]. Tese de Doutorado em Linguística. Universidade Estadual de Campinas, Instituto de Estudos da Linguagem.

. (2014). "O Ensino, a Leitura e a Escrita: sobre conectividade e mobilidade". In: Entremeios. v.9, jul/2014. Disponível em: $<$ http://www.entremeios.inf.br/published/198.pdf $>$. Acesso em jan. 2018

. (2016). "Não é só a morte que nivela’: o discurso da cultura digital". In: ORLANDI, E.; MASSMANN, D. (Orgs.). Cultura $e$ Diversidade. Trilogia Travessia da Diversidade. v.1. Campinas: Pontes Editores.

(2018). Análise do Discurso Digital: sujeito, espaço, memória e arquivo. Campinas: Pontes Editores.

FERREIRA, A. C. F. (2009). A Linguística entre os nomes da linguagem: uma reflexão na História das Ideias Linguísticas no Brasil. Tese (doutorado) - Universidade Estadual de Campinas. Campinas.

(2015). "O papel e o poder fundador da linguagem na reflexão sobre conhecimento e tecnologia". In: Entremeios, Seção Estudos, Programa de Pós-graduação em Ciências da Linguagem 


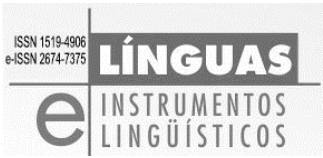

(PPGCL), Universidade do Vale do Sapucaí, Pouso Alegre (MG), v.11, p.75-98.

GUIMARÃES, E. (2002). Semântica do Acontecimento: um estudo enunciativo da designação. Campinas: Pontes.

. (2011). Análise de Texto: procedimentos, análises, ensino. Campinas: Editora RG.

; MOLLICA, M.C. (Orgs.). (2007). A palavra: forma $e$ sentido. Campinas: Pontes Editores, RG Editores.

.; ORLANDI, E. (1996). Língua e cidadania: o português no Brasil. Campinas: Pontes.

.; ORLANDI, E. (Orgs.). (2002). Institucionalização dos Estudos da Linguagem: a disciplinarização das Ideias Linguísticas. Campinas: Pontes.

(2013). "Autoridade da Informação". In: Revista Línguas e Instrumentos Linguísticos. Editora RG. v.31. Disponível em: <http://www.revistalinguas.com/edicao31/artigo1.pdf >. Acesso em dez. 2018.

MARIANI, B. (2004). Colonização Linguística: línguas, política e religião no Brasil (séculos XVI a XVIII) e nos Estados Unidos da América (século XVIII). Campinas: Pontes.

NUNES, J. H. (1996). "Aspectos da forma histórica do leitor brasileiro na atualidade". In: ORLANDI, E. A leitura e os leitores. Campinas: Pontes.

. (2006). Dicionários no Brasil. Análise e História do Século XVI ao XIX. Campinas: Pontes; São Paulo: Fapesp.

(2008). "O Discurso Documental na História das Ideias Linguísticas e o Caso dos Dicionários”. In: Alfa: São Paulo, 52(1), p.81-100.

. (2002). "Dicionarização no Brasil: condições e processos". In: NUNES, J. H.; PETTER M.. (Org.). História do Saber Lexical e Constituição de um Léxico Brasileiro. São Paulo/Campinas: Humanistas/Pontes, p.99-119.

ORLANDI, E. (1984). "Segmentar ou recortar?". Série Estudos. In: Linguística: questões e controvérsias, n.10. Uberada: Fiube.

(1990). Terra à vista. Discurso do confronto: velho e novo mundo. Campinas, Cortez Editora/Editora da Unicamp. 
INSTRUMENTOS LINGUÍSTICOS E DISCURSOS DE DISPONIBILIZAÇÃO DE/EM INSTRUMENTOS DIGITAIS DE APRENDIZAGEM

(Org.). (2001). História das Ideias Linguísticas: Construção do Saber Metalinguístico e Constituição da Língua Nacional. Campinas/Cáceres: Pontes/Unemat.

. (2002). Língua e Conhecimento Linguístico. A Gramática, o Estado, a Autoria. Campinas: Cortez Editora.

(2006). "Análise de Discurso". In: LAGAZZI, S.; ORLANDI, E. (Orgs.). Discurso e Textualidade. Campinas: Pontes. (2007a). Interpretação: autoria, leitura e efeitos do trabalho simbólico. São Paulo: Pontes Editores.

. (2007b). As formas do silêncio. Nos movimentos do sentido. Campinas, SP: Editora da Unicamp.

. (1983). "A escola e suas mediações: como se usa o material didático". In: Educação \& Sociedade. [Revista Quadrimestral de Ciências da Educação]. v.16.

. (2008). Discurso e Texto. 3.ed. Campinas: Pontes.

(2012). Discurso em Análise: sujeito, sentido, ideologia.

Campinas: Pontes.

(2015). "Linguagem, Conhecimento e Informação". Conferência proferida no evento Cidade Conectada: Discurso, interação e mobilidade. VIII Encontro Saber Urbano e Linguagem. Labeurb/Unicamp: Campinas.

O'REILLY, T. (2005). What Is Web 2.0: design patterns and business models for the next generation of software. Disponível em: <https://goo.gl/9rTM45>. Acesso em jan. 2018.

PFEIFFER, C. C. (1995). Que Autor é este?. Dissertação de Mestrado em Linguística. Universidade Estadual de Campinas. Campinas.

. (2000). Bem dizer e retórica: um lugar para o sujeito. Tese de doutorado em Linguística. Universidade Estadual de Campinas, Campinas.

(2011). "Língua, ensino e políticas públicas". In: Conforte, A.; Valente, A. C. (Orgs.). Saber a Língua, Saber da Língua. Rio de Janeiro: UERJ, v.1, p.97-109.

(2005). "O saber escolarizado como espaço de institucionalização da língua”. In: Sentido e Memória. GUIMARÃES, E.; BRUM-DE-PAULA, M. R. (Org.). Campinas: Pontes Editores.

. (2007). "A Linguística nas Associações: um recorte discursivo de sua institucionalização. Uma questão de política 


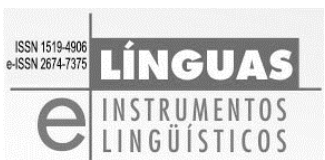

linguística”. In: ORLANDI, E. (Org.). Política Linguística no Brasil. Campinas: Pontes Editores, v.1, p.19-34.

PÊCHEUX, M. (1990). "Análise Automática do Discurso (AAD-69)". In: GADET, F. \& HAK, T. (Orgs.). Por uma análise automática do discurso: uma introdução à obra de Michel Pêcheux. Trad.: Bethânia Mariani [et al]. Campinas: Editora da Unicamp.

. (1999). "Papel da memória". In: ACHARD, P. et al. (Org.). Papel da memória. Trad. e Intro.: José Horta Nunes. Campinas: Pontes.

(1995). Semântica e discurso. Uma crítica à afirmação do óbvio. Trad.: Eni Pulcinelli Orlandi [et al.]. Campinas: Editora da Unicamp.

SILVA, M. V. (1998). História da Alfabetização no Brasil: a constituição de sentidos e do sujeito da escolarização. Tese de Doutorado em Linguística. Universidade Estadual de Campinas. Campinas.

Palavras-chave: Instrumentos Linguísticos, História das Ideias Linguísticas, Instrumentos digitais de aprendizagem.

Keywords: Linguistic Instruments, History of Language Ideas, Digital learning instruments.

\section{Notas}

${ }^{1} \mathrm{O}$ presente trabalho foi realizado com apoio da Coordenação de Aperfeiçoamento de Pessoal de Nível Superior - Brasil (CAPES) - Código de Financiamento 001.

* Doutoranda em Linguística no Instituto de Estudos da Linguagem da Universidade Estadual de Campinas (IEL/UNICAMP).

${ }^{2}$ Agradeço à prof ${ }^{a}$ Amanda Eloina Scherer pela contribuição da metáfora inicial deste texto, e também à orientação precisa, e preciosa como um cristal, da prof ${ }^{a}$ Ana Claudia Fernandes Ferreira, que tornou este texto possível para a qualificação na área da HIL pelo PPGL - IEL/UNICAMP.

3 A noção de entremeio (Orlandi, 1996), cara à Análise de Discurso, diz respeito a uma relação estabelecida por contradições, no espaço relacional entre as teorias, produzindo deslocamentos por meio de suas relações de sentido e de força.

${ }^{4}$ Sobre aspectos mais aprofundados neste assunto, ver Branco (2008).

5 A noção de instrumentos linguísticos (AUROUX, 1992) é pensada por uma abordagem discursiva da HIL do Brasil. Assim, a reflexão acerca dos discursos da e sobre a língua (ORLANDI, 2001) considera como instrumentos linguísticos

Líng. e Instrum. Linguíst., Campinas, SP, n. 44, p.78-111, jul./dez. 2019 
gramáticas e dicionários, e também manuais, cartilhas, enciclopédias, etc., como tecnologias de linguagem. Dito de outro modo, as pesquisas no âmbito da HIL, como os de Orlandi e Guimarães (1996), Nunes (1996, 2006), Silva (1998), Pfeiffer (2000), Orlandi (1990, 2001), Mariani (2004), Ferreira (2009), dentre outros, mostram a construção desses instrumentos linguísticos na relação com a constituição de um saber metalinguístico e a construção de uma língua nacional. Construção esta que considera esses instrumentos como objetos históricos, como discursos que têm seu caráter linguístico-histórico, político e ideológico.

${ }^{6}$ Nas noções de ordem e organização desenvolvidas por Orlandi, a primeira expressa como forma material do sentido e a segunda como tentativa constante de controle sobre os sentidos. (cf. Orlandi, 2007).

${ }^{7}$ Fazemos referência à pesquisa de Cristiane Dias (2004), que desenvolve em sua tese de doutorado reflexões sobre uma cartografia do digital, adotando uma perspectiva que considera, tanto política quanto ideologicamente, as relações do sujeito com o espaço em sua maneira de ser e estar nele.

${ }^{8}$ Cf. Pêcheux (1995, p.147): a memória discursiva é aquilo que já foi "dito em outro lugar, antes e independentemente" e que retorna. Orlandi (2006) distingue memória discursiva de memória metálica, sendo esta última "produzida por um construto técnico (televisão, computador, etc.). Sua particularidade é ser horizontal (...), não havendo assim estratificação em seu processo, mas distribuição em série, na forma de adição, acúmulo: o que foi dito aqui e ali e mais além vai-se juntando como se formasse uma rede de filiação e não apenas uma soma. Quantidade e não historicidade."

${ }^{9}$ A noção de recorte foi formulada por Orlandi (1984), e pode ser compreendida como uma unidade discursiva produzida sobre os materiais da análise.

${ }^{10}$ Conforme Pêcheux (1990), as condições de produção dizem respeito àquilo que deriva da estrutura de uma ideologia, correspondendo a um lugar determinado no interior de uma formação social dada, exterior à situação de discurso, mas que lhe é constitutiva, estabelecendo relações de forças e de dominância.

${ }^{11}$ É pertinente esclarecer que a HIL, tal como é feita no Brasil, se difere do fazer historiográfico, pois não toma o olhar externo, de uma certa posição de historiador, mas sim parte da posição do especialista em linguagem considerando a história, pois como afirma Ferreira (2009, p.41) “(...) recusar a ilusão de que se estaria fora da história ao contar uma história é reconhecer que a história deve ser considerada em relação ao sujeito, aos sentidos, à ideologia e à língua.”. Reconhecer a história nessa relação, é, como nos aponta Orlandi e Guimarães (2002), reconhecer a construção de um saber, da história da constituição de uma língua nacional que traz em si uma relação necessária entre língua, ciência e política, entre língua, conhecimento e Estado, numa tripla injunção entre o papel legislador do Estado, o papel regulador da instituição e a tradição gramatical. Nessa relação, a questão é de que modo essa injunção se dá no que se refere aos discursos que circulam no digital (Dias, 2004, 2014, 2016) considerando a constituição e a formulação de objetos de aprendizagem, tomados como tecnologias de linguagem. 


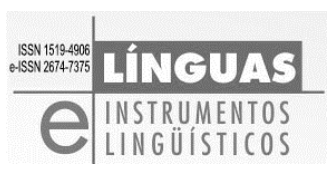

${ }^{12} \mathrm{Na}$ dissertação de Mestrado desenvolvida sobre os discursos sobre a leitura, trato do que chamei de discursos do incentivo tendo como um dos elementos os discursos de disponibilização.

${ }^{13}$ Conforme proposto por Pêcheux no Colóquio Materialidades Discursivas, a questão resulta de uma heterogeneidade irredutível, de uma relação entre a língua, a história e o inconsciente. cf. Bernard Conein et al., 2016.

${ }^{14}$ Noção inspirada em Pfeiffer (1995) e sua noção de sujeito urbano escolarizado. Ver Coelho (2016).

15 A nomeação desses espaços como repositórios está na relação com seu sentido de lugar para guardar uma coleção, objetos, etc., e difere da nomeação dada aos repositórios digitais que comumente designam espaços institucionais de disponibilização de produção científica. Assim, se pode colocar outra questão: sendo os repositórios tratados com a discursividade que os significa como saberes disponíveis, nomeá-los de repositórios digitais para marcar o lugar do saber científico estabelece uma relação de diferença entre o que é um saber científico e um saber escolar. Como os recortes de análise estão na relação direta com a escola, os repositórios são tratados como lugares onde se guardam esses saberes. Não vamos entrar nesta questão, mas destacamos que ela é interessante e importante para se pensar a divisão entre o que se produz como saber.

16 Disponível em: <http://portaldoprofessor.mec.gov.br/index.html> e <http://objetoseducacionais2.mec.gov.br/>. Acesso em dez. 2017.

${ }^{17}$ Tim O'Reilly, presidente da O'Reilly Media, empresa na qual Dale Dougherty atuou como co-fundador, em um artigo publicado no site de sua empresa, mostra algumas diferenças entre as duas webs, discute o futuro da web 2.0 e atribui o termo "web social" a Dougherty. Na mesma referência é possível também acompanhar as Conferências de O'Reilly sobre a web 2.0.

${ }^{18}$ Conforme Guimarães (2011, p.19), o "texto é uma unidade de sentido que integra enunciados no acontecimento da enunciação", e é caracterizado pela produção de sentidos, na integração de enunciados, atentando para o fato de que tal definição não considera uma unicidade de sentido para o texto ou a tomada do texto como uno. Assim, não há enunciado independente do texto, mas antes ele significa na relação "com sua consistência interna e com sua independência relativa quanto ao texto" em que há algo que o faz significar em virtude do próprio texto em que está formulado. (GUIMARÃES, 2007).

${ }^{19}$ Embora este trabalho não objetive analisar as políticas linguísticas aí inscritas, é preciso destacar que elas têm uma importância fundamental na HIL e por isso disponibilizamos as outras versões a seguir.

${ }^{20}$ Versão em Espanhol: "El repositorio Educativo es un espacio en el internet donde tenemos almacenados recursos digitales sobre la educación. Estos recursos pueden ser una imagen, pdf, página html, un audio, entre otros. Navegue en el repositorio y descubra todo lo que está listo para hacer de su estudio, enseñanza, investigación, más rico y didáctico. Actualmente, hay 19.842 objetos publicados y 174 están evaluando o en espera de la aprobación de los autores para su publicación."/ Versão em Português: "Este Repositório possui objetos educacionais de acesso público, em vários formatos e para todos os níveis de ensino. Acesse os objetos isoladamente ou em coleções.

Líng. e Instrum. Linguíst., Campinas, SP, n. 44, p.78-111, jul./dez. 2019 
Nesse momento o Banco possui 19.842 objetos publicados, 174 sendo avaliados ou aguardando autorização dos autores para a publicação.” (grifos nossos)

${ }^{21}$ Como afirma a pesquisa de Nunes $(1996 ; 2002 ; 2006 ; 2008)$, no que diz respeito aos estudos lexicográficos no Brasil, o dicionário tem um lugar na história das ciências da linguagem e é um instrumento linguístico que produz um imaginário sobre a língua na sociedade. Assim, é importante, conforme Nunes (2008, p.92), compreender a existência dos dicionários, sua aparição, transformação e substituição no espaço e no tempo.

${ }^{22}$ Há um número muito extenso de redes sociais de aprendizagem disponíveis na Internet. Nem todas as que aqui são citadas estão disponíveis para acesso. Algumas têm acesso apenas por meio de instituições educacionais com login e senha, outras já foram retiradas da Internet e podem ser relatadas por meio de notícias e arquivos em cache, tais como: Rede Conecta, com informação disponível em: < https://goo.gl/qqE53r >; EducaNetworks, com informação disponível em: <http://archive.is/0zgz9>. As redes que estão disponíveis para acesso público são: edmodo, disponível em: <https://www.edmodo.com/>; Teamie, disponível em: $<$ https://theteamie.com/>; Nova Escola Clube, disponível em: <http://novaescolaclube.org.br/>; Docsity, disponível em: <http://www.docsity.com/pt/>; EducaRedes, disponível em: <http://eduredes.ning.com/>; Brainly, disponível em: <http://brainly.com.br/>; OtraEducación, disponível em: <http://www.otraeducacion.es/>. Mais recentemente temos redes como o Google for education (disponível em: <https://goo.gl/7yQgcw >) e Microsoft $360^{\circ}$ (disponível em: <https://goo.gl/4SWfDo>) que se configuram não apenas como redes sociais educacionais, mas como plataformas de ensino com a disponibilização de diversos recursos digitais para educadores, escolas e alunos.

${ }^{23}$ Disponível em: 〈https://goo.gl/JupXvG〉 e <https://goo.gl/x4CDKx>, respectivamente.

${ }^{24}$ Disponível em: <https://goo.gl/VPg5zR>. Acesso em dez. 2017.

${ }^{25}$ Disponível em: <https://goo.gl/zSWNqw〉. Acesso em dez. 2017.

${ }^{26}$ Este subtítulo parte de um texto apresentado para a conclusão da disciplina LL 270 Seminário Avançado em Semântica, ministrada no primeiro semestre de 2016, no Instituto de Estudos da Linguagem da Unicamp, pelo prof. Eduardo Guimarães.

${ }^{27}$ Chamo a atenção aqui para o trabalho de Guimarães (2013), em que o autor mostra como a contestação é a forma mesma da sustentação do argumento de autoridade do Google na máxima "Se não está no Google, não existe".

${ }^{28}$ A inscrição de uma relação linguística na história, de um enunciado como acontecimento linguístico, permite a Guimarães (2002) esclarecer que, ao tratar dos nomes próprios, não está tratando nem de nomeação e muito menos de denotação, mas sim de designação como significação de um nome.

${ }^{29}$ Para Guimarães (2002, p.11), na enunciação, como acontecimento de linguagem, há dois elementos definitivos para sua conceituação: língua e sujeito que se constituem pelo funcionamento da língua na qual se enuncia alguma coisa. Segundo o autor, "a enunciação é o evento do aparecimento de um enunciado" - tomada como funcionamento da língua sem remeter isto a uma centralidade do sujeito. O locutor nesta concepção é o que fala, o que assume a palavra e põe-se no lugar de quem enuncia, e para tanto é preciso que o locutor não seja ele próprio, mas "um lugar social de locutor" (idem, 2007, p.24), afetado pelos lugares sociais autorizados e pelo interdiscurso. 
${ }^{30}$ Os memes podem ser descritos como imagens que circulam nas redes sociais, se propagando rapidamente, produzindo um efeito de replicação pelo funcionamento da memória metálica (ORLANDI, 2007). Considerados como um discurso de imagens que circula e produz efeitos.

${ }^{31}$ E este sujeito, ao enunciar, é tomado pela temporalidade do acontecimento. Como afirma Guimarães (2002, p.12): “O acontecimento instala sua própria temporalidade: essa a sua diferença."

32 Destacamos aqui a pesquisa de Ferreira (2015) sobre o Google como tecnologia de informação - na relação com as tecnologias de linguagem, em que a autora analisa o enunciado "A missão do Google é organizar as informações do mundo e torná-las mundialmente acessivieis e úteis", apontando para os efeitos de sentido produzidos por esta formulação da missão da empresa na página "Sobre o Google".

${ }^{33}$ Disponível em: 〈https://bit.ly/2Gpkmkx>. Acesso em mar. 2018.

${ }^{34}$ Disponível em: <https://educapes.capes.gov.br/>. Acesso em jan 2018. 